\title{
Therapeutic Plasma Exchange and Conservative Treatment Comparison in Patients with Hypertriglyceridemia- induced Acute Pancreatitis
}

\author{
Hipertrigliseridemi Ilişkili Akut Pankreatit Hastalarında \\ Plazma Değişimi ve Konservatif Tedavinin Karşılartırı. \\ apötı
}

(D) Altay Kandemir ${ }^{1}$, (D) İsmail Taşkıran ${ }^{1}$, (D) Sezgin Vatansever ${ }^{2}$, (D) Mustafa Çelik ${ }^{3}$, (D) Irran Yav (D) Adil Coşkun ${ }^{1}$, (D) Mehmet Hadi Yaşa ${ }^{1}$

\footnotetext{
${ }^{1}$ Aydın Adnan Menderes University Faculty of Medicine, Department of Gastroent

${ }^{2}$ Izmir Katip Çelebi University Atatürk Training and Research Hospital, Clinic of Gr

${ }^{3}$ Pamukkale University Faculty of Medicine, Department of Gastroen"

${ }^{4}$ Aydın Adnan Menderes University Faculty of Medicine, Departmen

${ }^{5}$ Aydın Adnan Menderes University Faculty of Medicine, Departn t of Biostatis
} $4^{4}$, (1) 'evlüt Th
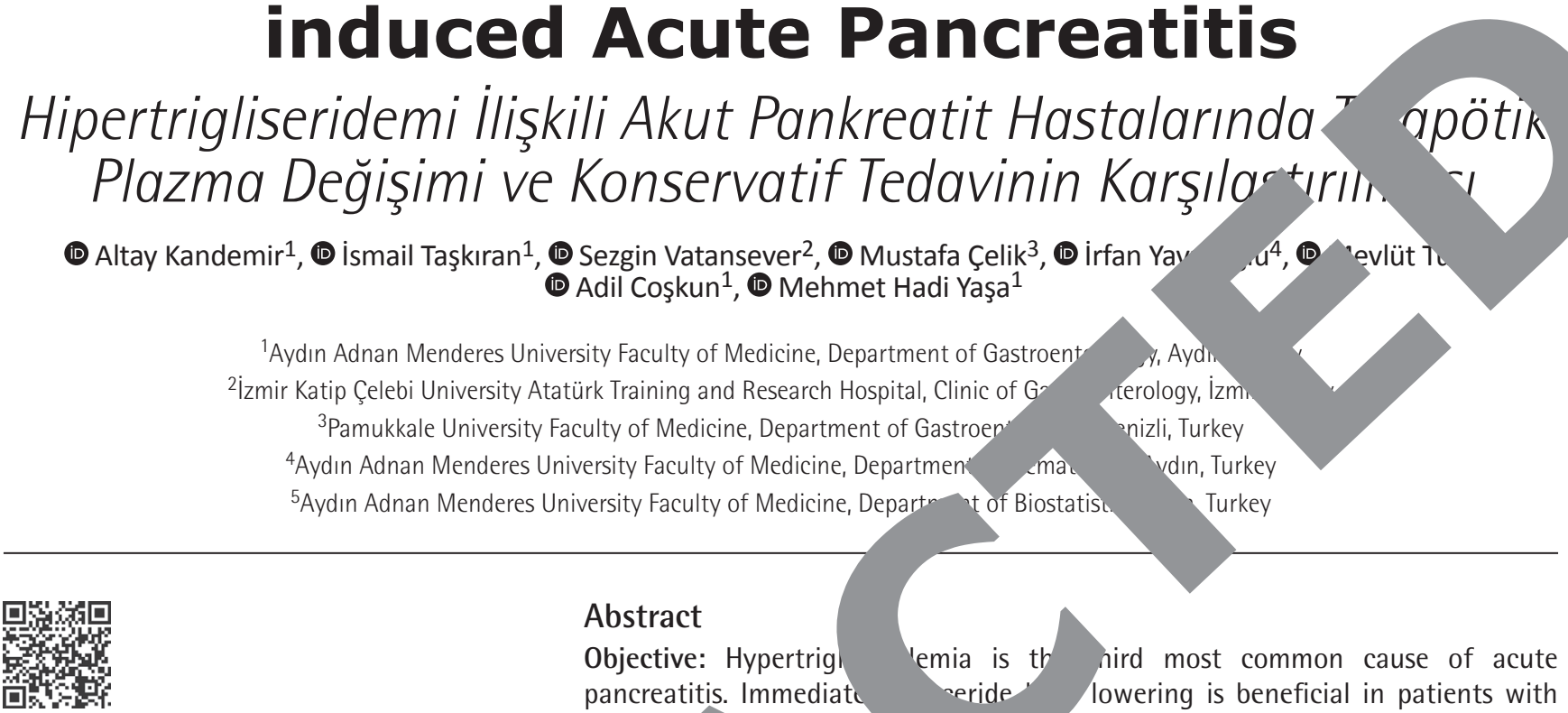

Keywords

Conservative treatment, hypertriglyceridemiainduced acute pancreatitis, therapeutic plasma exchange

Anahtar Kelimeler Konservatif tedavi, hipertrigliserider akut pankreatit, terapötik plazma do

Received/Geliş Tarihi Accepted/Kabul Tarihi $: 23$ .2021 doi:10.4274/meandr r

Address for $\mathrm{C}$ Altay Kand Aydın A Medicin Aydın, Turk

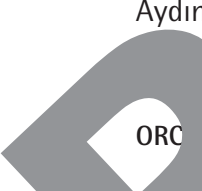
$:+902$ altaykar : orcid.org/00 -0002-2918-3811

canurou al and Dental Journal, Published by nos Publishing House.

article distributed under the terms of the

Commons Attribution NonCommercial 4.0 onal Licence (CC BY-NC 4.0).

\section{Abstract}

Objective: Hypertrig pancreatitis. Immediat severe h. -ialyceridem compa tov of acu

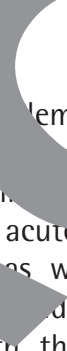

with hyp npom treatment servativ iment.

erials Methods: A total of 120 patients diagnosed with ertriglyce mia-induced acute pancreatitis treated with TPE in addition ve treatment (group 1) or conservative treatment only (group 2) participu d in the study.

Results: Group 1 consisted of 38 patients (9 females and 29 males) and group 2 82 patients (29 females and 53 males). No difference was found between the wo groups regarding patient characteristics. The TG levels in group 1 decreased by $56.8 \%$ in one treatment session. The rate of patients with moderately severe acute pancreatitis + severe acute pancreatitis in group 1 was $36.8 \%$, whereas $59.8 \%$ in group 2 ( $p=0.029$ ). The local complication rate was $34.2 \%$ and $57.3 \%$ in group 1 and group 2 , respectively $(p=0.031)$. No significant difference was found between the groups regarding organ failure, systemic complication, hospitalization duration, and in-hospital mortality rates.

Conclusion: Our study revealed that TPE treatment is effective in reducing local complications (especially pancreatic pseudocyst).

Öz

Amaç: Hipertrigliseridemi akut pankreatitin en sık 3 nedeninden biridir. Ciddi hipertrigliseridemisi olan hastalarda [trigliserid (TG) $>1.000 \mathrm{mg} / \mathrm{dL}$ ] TG düzeyinin hemen düşürülmesi faydalı olabilir. Çalışmamızda hipertrigliseridemi ilişkili akut 
pankreatit hastalarına uygulanan konservatif tedavi ile konservatif + terapötik plazma değişimi tedavilerini mortalite, hastane yatış süresi ve lokal-sistemik komplikasyonları baz alarak karşılaştırdık.

Gereç ve Yöntemler: Hipertrigliseridemi ilişkili akut pankreatit tanısı olup konservatif tedavi + terapötik plazma değişimi tedavisi alanlar (grup 1) ve sadece konservatif tedavi alan (grup 2) toplam 120 hasta çalışmaya alınmıştır.

Bulgular: Grup 1'de 38 (9 kadın, 29 erkek), grup 2'de 82 (29 kadın, 53 erkek) hasta mevcuttu. İki grup arasında hasta özellikleri açısından fark yoktu. Grup 1'de bir seans tedavi sonrası TG düzeyi \%56,8 azaldı. Grup 1 hastalarının \%36,8'i orta + ciddi düzeyde pankreatit iken, grup 2 hastalarında bu oran \%59,8 idi ( $p=0,029)$. Lokal komplikasyon oranları grup 1 ve grup 2 hastalarda sırası ile $\% 34,2$ ve $\% 57,3$ idi $(p=0,031)$. Gruplar arasında organ yetmezliği, sistemik komplikasyonlar, hastane yatış süresi ve hastane içi mortalite açısından fark yoktu.

Sonuç: Çalışmamızda, terapötik plazma değişimi tedavisi lokal komplikasyonları (özellikle pankreatik psödokist) azaltmada etkili olarak bulunmuştur.

\section{Introduction}

Acute pancreatitis (AP) is a common disorder having high morbidity and mortality. Although the majority of patients have a mild clinical course, the mortality rate may reach $30 \%$ in patients with severe pancreatitis (1). Hypertriglyceridemia (HTG) is the third most common cause of AP following gallstones and alcohol; it is responsible for $1-10 \%$ of AP cases (2). HTG may be primary, or it may develop secondary to alcohol abuse, diabetes mellitus (DM), pregnancy, obesity, hypothyroidism, nephrotic syndrome, or various medications such as $\beta$-blockers, oral retinoids. It is believed that AP risk is elevated in patients with triglyceride (TG) level above 1,000 mg (3). HT has been reported to be more related to morta severe pancreatitis, complications, and recurren compared to other AP etiologies (4-6). Therefore, is important to assess the severity and nosis of patients with hypertriglyceridemipancreatitis (HTG-AP) in the early od; th elps in both individualizing the treatmen, im prognosis of the disease. T althaz e plays an important role in deter a the seve, AP and has been in use for $C$ decades $(7,0$

The treatment $\mathrm{p}$, ciple $\mathrm{P}$ are fasting, lowcalorie infusic $n$ theacute $\quad$, using anti-lipid agents (fer ate, remfibrozil, in, omega-3 fatty acids), oler weight heparin (LMWH), and insulin. $\Lambda$ nacole cal treatment methods sy the ric na exchange (TPE) have be us icly.

In ar study, we aimed to compare our an ated HTG-AP patients to our HTG-AP nts In wn...m TPE was added to the conservative t. ent method, regarding AP severity, duration of hos zation, in-hospital mortality, organ failure, and local/systemic complication rates, $b_{c}$, n the revised Atlanta classification.

\section{Materials and Methor}

Study Population

A total of $120 p$ mean age of 41.1 is (38 fer. nosed as $\mathrm{H}_{\mathrm{i}}$ and treated with conserva m only or with TPE added to conser treatm gastroenterology depart is of the three di. it university hospitals were olled in this study. While TPE + conservative trea t was perf ned in one university hospital, only rvative ${ }^{+}$iment was administered in the other thospitals. All patient data were rospectivury obtained from the electronic medical The diagnosis of HTG-AP was made based els above $1,000 \mathrm{mg} / \mathrm{dL}$ and the presence at least two of the three diagnostic criteria for AP abdominal pain, more than 3-fold increased serum pase level, and characteristic imaging findings). We did not perform the genetic analysis to determine the type of hyperlipidemia in our patients.

Patient data were recorded including age, gender, alcohol consumption, the presence of diabetes mellitus, previous AP exacerbations and related therapeutic apheresis, together with previous medical treatment for hyperlipidemia. Also, values of fasting blood glucose, blood urea nitrogen, creatinine, calcium (Ca), alanine aminotransferase, lactic dehydrogenase, amylase, lipase, TG, C-reactive protein (CRP), leukocyte, hematocrit were collected for each patient. The reduction in TG was calculated using the values at admission and the day after TPE. Contrast-enhanced CT scans of the abdomen were performed within the three days following admission in all patients. The Balthazar score was confirmed by 
two independent radiologists. Clinical course was reevaluated after 24,48 and $72 \mathrm{~h}$. Local complication was re-evaluated after 48-72 $\mathrm{h}$ and 4 weeks. The severity of pancreatitis was determined taking into account the overall course of the patient after discharge. According to the 2012 revision of the Atlanta classification and the definitions by international consensus, the severity of AP was categorizedin three groups as mild acute pancreatitis (MAP), moderately severe acute pancreatitis (MSAP), and severe acute pancreatitis (SAP). MAP lacks organ failure, local or systemic complications, and exacerbation of coexisting disease. The MSAP manifests transient organ failure $(\leq 48$ hours), local complications, and/or exacerbation of coexisting disease. SAP is defined by persistent organ failure ( $\geq 48$ hours). Organ failure involves pulmonary failure, defined as an arterial $\mathrm{PO}_{2}<\mathrm{mmHg}$ on room air or the requirement for mechanical ventilation. Cardiovascular failure is defined as the development of shock (systolic pressure $<90 \mathrm{mmHg}$ ) that persists following fluid resuscitation. Renal failure is defined as a serum creatinine level $>2 \mathrm{mg} / \mathrm{dL}$ after rehydration or the need for hemodialysis in patients wit preexisting renal disease. Local complicat are acute peripancreatic fluid collection (APF pancreatic pseudocyst, walled-off sis, an necrosis. The systemic complication d as an exacerbation of preexisting com dity, $\mathrm{p}$ ipitated by AP (9). The patients were div as treated with TPE in a on to onservative treatment (group 1) reated wit. servative treatment only (gr ospital mol ity, organ failure, duration of rospita. n, local and systemic complicatior is were com between the two groups.

The ' $v$ ' nics committee approval was obtained Ae Adp Menderes University Nonotu as cond (protocol no: 2017/1253, date: 26.1 017) se Treatment

travenous hydration and pain management were a tered in addition to the discontinuation of oral feearng. LMWH was used for thrombosis prophylaxis. Insulin was administered when glucose level was $>150 \mathrm{mg} / \mathrm{dL}$.

\section{Plasma Exchange Procedures}

A haemonetics MCS + (Haemonetics Corp. Braintree, USA) was used in all TPE procedures. Vascular access was obtained with a double-or singlelumen catheter usually placed in the femoral vein; peripheral veins were used for the return of hand in some cases. A central venous catheter in cases with the inappropriate vascu' each TPE session, one (rarely up to th timated plasma volume was exchanged $d$ rep a bicarbonate-based electro solution $\mathrm{g} / \mathrm{L}$ albumin added. Antic achieved with unfractiona citrate (either $4 \% \quad .5 \%$ s included intraver

a substitut.

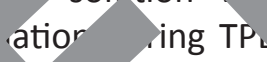
with ation ing $\mathrm{TP}_{\mathrm{L}}$ is

\section{Statistical}

The data whe ana hy using Statistical Package for Sor ces versic (SPPP, Inc.; Chicago, IL, USA e descriptive statis, of categorical variables we corded as number (\%), and the chi-square test was $d$ for inter up comparison. The conformity of co sles to anormal distribution was assesse .olmogorov-Smirnov test. Since age a normal distribution, its descriptive statistical re shown as mean \pm standard deviation,

d trie t-test in independent groups was used for the comparison of the two groups. Since the other continuous variables were not normally distributed, their descriptive statistical results were shown as median (25-75\%), and the Mann-Whitney $U$ test was used for intergroup comparison of these variables. The chi-square automatic interaction detector analysis was used to determine the factors effective in identifying the presence of local complications. $\mathrm{P}<0.05$ was considered as statistically significant.

\section{Results}

A total of 120 patients were included in the study between January 2007-January 2019. Group 1 included 38 patients ( 9 females and 29 males, mean age of $40.3 \pm 7$ ), and group 2 included 82 patients ( 29 females and 53 males, mean age of $41.6 \pm 10.7)$. The patient characteristics were summarized in Table 1. No significant difference was found between the groups regarding age and gender. There were $17 \mathrm{DM}$ patients in group 1 (44.7\%), whereas DM was present in 33 patients in group $2(40.2 \%)(p=0.800)$; insulin 
infusion was administered in all of these patients. LMWH was administered in all patients in doses of venous thromboembolism. The time between the initiation of abdominal pain or hospital admission and plasma exchange procedure was $10 \pm 4$ (range 4-24) hours in average.

TPE was well-tolerated. Vomiting in six patients, palpitation and tachycardia in four patients, asymptomatic hypotension in three patients, occurred. Two cases had hypervolemia which was successfully treated with IV furosemide. Hemolysis was not detected in any of the patients. Occlusion of the catheter was seen in one patient. TPE was discontinued in none of these patients.

When the patients were evaluated according to the revised Atlanta classification, $24 \operatorname{MAP}$ (63.2\%), 11 MSAP (28.9\%) and 3 SAP (7.9\%) patients were found in group 1 and $33 \operatorname{MAP}(40.2 \%), 39 \operatorname{MSAP}(47.6 \%)$ and 10 SAP (12.2\%) were found in group 2 . When the patients were redistributed as MAP and MSAP+SAP, the ratio of MSAP+SAP was 36.8 in group 1, whereas it was $59.8 \%$ in group 2 ( $p=0.029)$.

There was no significant difference between th groups regarding organ failure (pulmonary failu. renal failure, and cardiovascular failure) $(p=0.680$ (Table 2). The local complications were summarized in Table 2.
Systemic complicationswere observed in two (5.3\%) patients in group 1 and five patients (6.1\%) in group 2 $(p=0.610)$. The mean duration of hospitalization was found as 6 (4-8) days in group 1 and 5 (3.75-8) days in group 2 . The in-hospital mortality rate was found as $2.6 \%$ in group 1 and $2.4 \%$ in group 2 . The overall in-hospital mortality rate, covering all patier $2.5 \%$.

There was no difference between grou, arding the initial TG level $(p=0.078)$. The $p$ ana TPE levels of TG were found as 1,57 ,406-3,32. $\mathrm{dL}$ and $682(454-1,107) \mathrm{mg} /$ sespe ely (1. 3). The TG level was found 4 ed by $56.8 \%$ following one TPE sessir the a time yeen the onset of abdomi sain or the the hospital and the exchange, dure was $11 \pm 3.9$ (range 4 , ho

No sigr ent relatic betwee - initial TG or CR is and local/systemic comp ons and the in-hospital mortality rate.

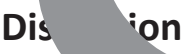

HTG h one of the significant causes of to changes in living conditions and lifestyle. The raphic characteristics of patients can be
li as, sung, male, with secondary factors such as $\checkmark$ and alcohol abuse, and frequently, the previous

\begin{tabular}{|c|c|c|c|}
\hline & & Group 2, n=82 & $p$ \\
\hline Age (year) & 40. & $41.6 \pm 10.7$ & 0.497 \\
\hline Male gender (\%) & 76.3 & 64.6 & 0.285 \\
\hline Leukocyte $\left(\mathrm{mm}^{3}\right)$ & 13.250 (9. J-17.815) & $11,300(8,800-14,500)$ & 0.059 \\
\hline Htc (\%) & $44.3(38.4-45.8)$ & $41.5(36-44)$ & 0.051 \\
\hline $\mathrm{LDH}(\mathrm{U} / \mathrm{L})$ & $(161-281)$ & 256 (201-295) & 0.067 \\
\hline $\mathrm{Ca}(\mathrm{mg} / \mathrm{dL}$ & $9.2(8.7-9.5)$ & $8.9(8.3-9.3)$ & 0.052 \\
\hline Glucose (mg, & $124(100-240)$ & $153(106-276)$ & 0.578 \\
\hline$(U / L)$ & $212(70-528)$ & $253(103-725)$ & 0.226 \\
\hline ceric & $1579(1.406-3.323)$ & $1,350(1,104-1,751)$ & 0.078 \\
\hline Known story & $15(39.5 \%)$ & $33(40.2 \%)$ & 1.000 \\
\hline 1. & $11(28.9 \%)$ & $24(29.3 \%)$ & 1.000 \\
\hline abuse (\%) & $6(15.8 \%)$ & $11(13.4 \%)$ & 0.950 \\
\hline DN. & $17(44.7 \%)$ & $39(40.2 \%)$ & 0.800 \\
\hline Pregna.cy (\%) & $3(7.9 \%)$ & $1(1.2 \%)$ & 0.250 \\
\hline
\end{tabular}


history of pancreatitis (10). In our study, also, the patients were young (mean age $41.1 \pm 8$ ), mostly male (68.3\% male), with a previous history of pancreatitis (29.6\%), DM (46.7\%), and alcohol abuse (14.2\%).

The probable mechanism of HTG-AP is hydrolysis of plasma TG into free fatty acids by pancreatic lipase, which are toxic to pancreatic endothelium and acinar cells (4). Conservative treatment (fasting, lipidlowering drugs, intravenous hydration) is not strong enough in reducing excessively elevated TG levels in patients with HTG-AP (11). In contrast, plasmapheresis might remove excessive lipid from serum in about two hours. Although the benefit of plasmapheresis is considered to be due to the rapid reduction of TG levels, removing significantly increased proteases from the blood and replacing the depleted protease inhibitors might also be augmenting the treatment process (12). Since its first description by Betteridge et al. (13) in 1978, numerous case reports (12) and case series (14) have been published about the use of plasmapheresis in the treatment of patients with HTG-AP. There is no randomized controlled study demonstrating the superiority of plasmapheresis against conservative treatment. However, it is recommended as a category III indication in the recent guideline (disorder for which the optimum role of apheresis therapy is + established, the individualized decision is necessary) in acute hypertriglyceridemic pancreatitis (15).

While reduction of TG level is achieved at the first or the second day of plasmapheresis, it is achieved in the following days of conservative treatment, and usually, it does not show a linear course. The clinical data about the effectivity of apheresis are limited by relief of clinical symptoms such as abdominal pain, nausea, vomiting, and laboratory findings an as triglyceride level. There are few studiec effects of apheresis on the severity $c$ (16) and Lennertz et al. (17) reporte Yeh et achieved improvements in TG le' 's up $i$ and ir clinical status and laboratory ags of the, In our study also, we achie a 56 , eductic levels in TPE group after 0 .

The computed grap is a widely user rical imag. verity $-x$ (CTSI) system in patients with o h is positiv orrelated with mortality a. dev ent of complications $(7,8)$. CTSI how volur ize, and contour of the pan s, together with ounding tissue lesions. It also guide in diagnosis and staging of AP by st ig pancrea necrosis and fluid collection. In on $\quad \mathrm{V}$, it w $=$ lown that CTSI could predict the progi orrectly 48-72 hours after admission

\begin{tabular}{|c|c|c|c|}
\hline & Groul, & Group 2, n=82 & $p$ \\
\hline Local complication (\%) & $13(34$. & 47 (57.3\%) & 0.031 \\
\hline APFC (\%) & $10(26.3$ & $31(37.8 \%)$ & 0.249 \\
\hline Pancreatic pseudocyst (\%) & $0(0 \%)$ & $9(10.9 \%)$ & 0.023 \\
\hline Walled-off necrosis + & o) & $1+6(8.6 \%)$ & 0.732 \\
\hline Systemic complication & $2(5.3 \%)$ & $5(6.1 \%)$ & 0.610 \\
\hline Median hospitz & $6(4-8)$ & $5(3.75-8)$ & 0.345 \\
\hline CRP>150 (\%) & $9(23.7 \%)$ & $8(9.8 \%)$ & 0.145 \\
\hline Balthazar scor & $13(34.2 \%)$ & $47(57.3 \%)$ & 0.031 \\
\hline Pulmonar & $2(5.3 \%)$ & $6(7.3 \%)$ & \multirow{3}{*}{0.680} \\
\hline Renal & $2(5.3 \%)$ & $5(6.1 \%)$ & \\
\hline Cardiova & $1(2.6 \%)$ & $4(4.9 \%)$ & \\
\hline & $1(2.6 \%)$ & $2(2.4 \%)$ & 0.820 \\
\hline
\end{tabular}

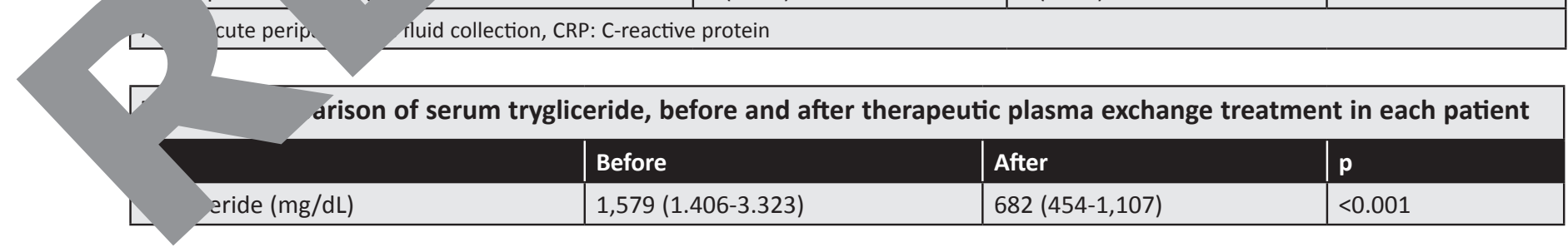


to the hospital (18). CTSI scoring system has a superior performance in predicting local complications in patients with HTG-AP $(19,20)$. Lloret Linares et al. (21) reported that severe pancreatitis (need for intensive care, CRP $>150 \mathrm{mg} / \mathrm{dL}$ or Balthazar score $>$ C) had been observed in $71.5 \%$ of patients. However, no relationship was observed between TG levels and the disease severity. In our study, the rate of patients with CRP $>150 \mathrm{mg} / \mathrm{dL}$ or Balthazar score $>\mathrm{C}$ was found as $55.8 \%$. No significant associations of initial TG level and CRP levels with in-hospital mortality and local/ systemic complication rates were observed.

The use of plasmapheresis is limited due to its high cost in addition to its unavailability in every hospital. Thus, many healthcare centers offer only conservative treatment for their patients with HTG-AP. Due to the lack of randomized controlled studies, it is not certain whether plasmapheresis improves mortality and morbidity in patients with HTG-AP or not. Gubensek et al. (14) reported that there was no relationship between initial TG levels and severity of the disease, mortality rates and hospital staying period. Plasma exchange, performed for once or twice, resulted in the reduction of TG faster than expected. Plasma exchange was found to be related to the low complication rate. The in-hospital mortality rate was found to $h$ low (5\%), and the delay in plasma exchange the had not affected the hospital mortality. In a study Nakhoda et al. (22), it was reported that, althoug TG levels were found to be reduced $v$, there was no significant difference betwe postTPE evaluated Acute Physiology Chror Health Evalation II (APACHE scores).

In a retrospective study HTG-AP patients were ded into th sups as non-plasmapheresis, $\quad$, and plas, neresis (group 2), TG levels ere fo be $65.8 \%$ reduced in plasmaphe group. The as no significant difference veen the two gs $\mathrm{s}$ and also the patients sev ancreatitis (defined by Ranson's score $>3$, ig tot mortality, systemic and Io - omplic rat $A$ the study of $\mathrm{He}$ WH et aring patients treated with highvolum iemofiltra on (HVHF) or LMWH + insulin, My atment was found to be superior in ing luv vels, whereas no significant differences v. und in terms of local pancreatic complications $(p>c$, , need for surgical intervention $(p=0.49)$, mortality rate $(p=0.49)$, and duration of hospitalization $(p=0.144)$ (24). Wang et al. (25) conducted a study on 144 HTG-AP patients treated with conservative treatment, and 91 (63.1\%) of patients were classified as MSAP and SAP. APFC, acute necrotic collections, and pseudocyst were observed in 66 (45.8\%), 13 (9\%) and $5(3.5 \%)$ of their patients as local complications, respectively. Systemic complications developed in 6 (4.2\%) patients, whereas mortality was observod in 8 (5.5\%) patients. MSAP and SAP, together complications and mortality were found to elevation of TG level.

In our retrospective study, we di ded o according to the revised Atlan+ assificatio and MSAP+SAP rates were 6 1 , whereas these rates were. 2 , respectively $(p=0.0$ ) oca dicatio e was and $3 \%$ in 8 $34.2 \%$ in group 1 ar $\quad .3 \%$ in gro $r, 31)$. The occurrence of $A^{r} \quad$ walled-off 1 sis+necrosis were found th sil in two groups. Pancreatic pseudocy as not ob. $\checkmark$ in group 1, whereas it was served in 9 (10. patients in group 2 $(p=0$ (Table 2). Total in-hospital mortality rate was ad to be $2 \%$. There were no statistically signit differen between the groups regarding organ mic complication, duration of coitalizatıu, and in-hospital mortality rates. it was observed that TPE treatment led mplicant reduction of AP severity and local
mplicate since TPE is consistently helpful uring the acute inflammatory phase.

The limitation of our study was its retrospective design. Also add to the limitations of the study, that due to its design (3 different hospitals) the effect of other differences in treatment practices or patient characteristics on outcome cannot be excluded. The distinguishing feature of our study is that it is the first study comparing HTG-AP patients having TPE with those having conservative treatment in terms of mortality, length of hospitalization, disease severity, local and systemic complications, in accordance with the revised Atlanta classification.

\section{Conclusion}

Plasmapheresis is an effective and useful method in reducing the excessively high TG levels in patients with HTG-AP. However, the use of plasmapheresis is limited to specific centers since it is a quite expensive 
treatment option. Apheresis should be continued until the TG level is reduced below 500-1,000 mg/dL. TPE may be effective in reducing local complications (especially pancreatic pseudocyst) but has no effect on organ failure and hospitalization duration; and optimal timing or how to select appropriate patients for this modality remains to be elucidated in further studies.

\section{Ethics}

Ethics Committee Approval: The study's ethics committee approval was obtained from the Adnan Menderes University Non-Invasive Clinical Research Ethics Committee that the study was conducted (protocol no: 2017/1253, date: 26.10.2017).

Informed Consent: All patient data were retrospectively obtained from the electronic medical records

Peer-review: Externally peer-reviewed.

\section{Authorship Contributions}

Concept: A.K., I.Y., M.Ç., Design: I.T., A.C., S.V., Fundings: M.H.Y., Data Collection or Processing: A.K., S.V., M.Ç., I.Y., A.C., Analysis or Interpretation: M.T., Literature Search: I.T., A.K., Writing: A.K., I.T., Critical Review: A.K., M.H.Y.

Conflict of Interest: No conflict of interest was declared by the authors.

Financial Disclosure: The authors declarec this study received no financial support.

\section{References}

1. Whitcomb DC. Clinical practice. Acy 2006; 354: 2142-50.

2. Valdivielso $P$, Ramírez-Buen hypertriglyceridemic pa 689-94.

3. Yadav D, Pitchum Clin Gastroentero, -003; 36

4. Hofbauer riess $\mathrm{H}$, We Schillir, et al. Hyperlipa ntensifiesthecourse of acl ematr acutenecrotisingpancreatitis in therat. Gut -8 .

5. Huang Jiang Jang SB, Li MX, Yang BH. Incidence d clinica yperlipidemic acute pancreatitis from ngdong, retrospective multicenter study. Pancreas 4; 43: 548-5

6 ski BJ, Cote GA, Pitt HA, Zyromski NJ. Systematic reviev nypertriglyceridemia-induced acute pancreatitis: A more virulent etiology? Pancreatology 2016; 16: 469-76.
7. Balthazar EJ, Ranson JH, Naidich DP, Megibow AJ, Caccavale $\mathrm{R}$, Cooper MM. Acute pancreatitis: prognostic value of CT. Radiology 1985; 156: 767-72.

8. Sahu B, Abbey P, Anand R, Kumar A, Tomer S, Malik E. Severity assessment of acute pancreatitis using CT severity index and modified CT severity index: Correlation with clinical outcomes and severity grading as per the Revised Atlanta Classification. Indian J Radiol Imaging 2017; 27: 152-60.

9. Banks PA, Bollen TL, Dervenis C, Gooszen HG, Johnson CD, Sarr $M G$, et al. Classification of acute pancreatitis--2012: rovision of the Atlanta classification and definitions by consensus. Gut 2013; 62: 102-11.

10. Click B, Ketchum AM, Turner R, Whitcomb pachristou G Yadav D. The role of apheresis in hypertrigly ia-inducec acute pancreatitis: A systematic revi 313-20.

11. Ewald N, Kloer HU. Severe for apheresis? Atheroscler $\mathrm{S}$

12. Yeh JH, Chen $\mathrm{JH}, \mathrm{Cr}$ pancreatitis. J Clir

13. Betteridge $D^{\prime}$ $\mathrm{M}$, Taylor KG criglyc nia: an $015 ; 1$ Galton D! by plasma t.change. 1978; $1: 1368$.

14. G Buturovic-P Romozi K, Ponikvar R. Factors ang outcome in acul, pertriglyceridemic pancreatitis ated with plasma exchange: an observational cohort study. S One 2014; 9 : 02748.

15. artz J, Pad abhan A, Aqui N, Balogun RA, Connelly$\Lambda$, et al. Guidelines on the Use of Therapeutic Aphu inical Practice-Evidence-Based Approach from the Writing Committee of the American Society for Apheresis: The th Special Issue. J Clin Apher 2016; 31: 149-62.

. I JH, Lee MF, Chiu HC. Plasmapheresis for severe lipemia: comparison of serum-lipid clearance rates for the plasmaexchange and double-filtration variants. J Clin Apher 2003; 18: 32-6.

17. Lennertz A, Parhofer KG, Samtleben W, Bosch T. Therapeutic plasma exchange in patients with chylomicronemia syndrome complicated by acute pancreatitis. Ther Apher 1999; 3: 227-33.

18. Greer SE, Burchard KW. Acute pancreatitis and critical illness: a pancreatic tale of hypoperfusion and inflammation. Chest 2009; 136: 1413-9.

19. Qiu L, Sun RQ, Jia RR, Ma XY, Cheng L, Tang MC, et al. Comparison of Existing Clinical Scoring Systems in Predicting Severity and Prognoses of Hyperlipidemic Acute Pancreatitis in Chinese Patients: A Retrospective Study. Medicine (Baltimore) 2015; 94: e957.

20. Yang L, Liu J, Xing Y, Du L, Chen J, Liu X, et al. Comparison of BISAP, Ranson, MCTSI, and APACHE ॥ in Predicting Severity and Prognoses of Hyperlipidemic Acute Pancreatitis in Chinese Patients. Gastroenterol Res Pract 2016; 2016: 1834256.

21. Lloret Linares $C$, Pelletier AL, Czernichow S, Vergnaud AC, Bonnefont-Rousselot D, Levy $\mathrm{P}$, et al. Acute pancreatitis in a 
cohort of 129 patients referred for severe hypertriglyceridemia. Pancreas 2008; 37: 13-2.

22. Nakhoda S, Zimrin AB, Baer MR, Law JY. Use of the APACHE II score to assess impact of therapeutic plasma exchange for critically ill patients with hypertriglyceride-induced pancreatitis. Transfus Apher Sci 2017; 56: 123-6.

23. Chen JH, Yeh JH, Lai HW, Liao CS. Therapeutic plasma exchange in patients with hyperlipidemic pancreatitis. World J Gastroenterol 2004; 10: 2272-4.
24. He WH, Yu M, ZhuY, Xia L, Liu P, Zeng H, etal. Emergent Triglyceridelowering Therapy With Early High-volume Hemofiltration Against Low-Molecular-Weight Heparin Combined With Insulin in Hypertriglyceridemic Pancreatitis: A Prospective Randomized Controlled Trial. J Clin Gastroenterol 2016; 50: 772-8.

25. Wang SH, Chou YC, Shangkuan WC, Wei KY, Pan YH, Lin HC. Relationship between Plasma Triglyceride Level and Severity of Hypertriglyceridemic Pancreatitis. PLoS One 2016; 11: e0163984.

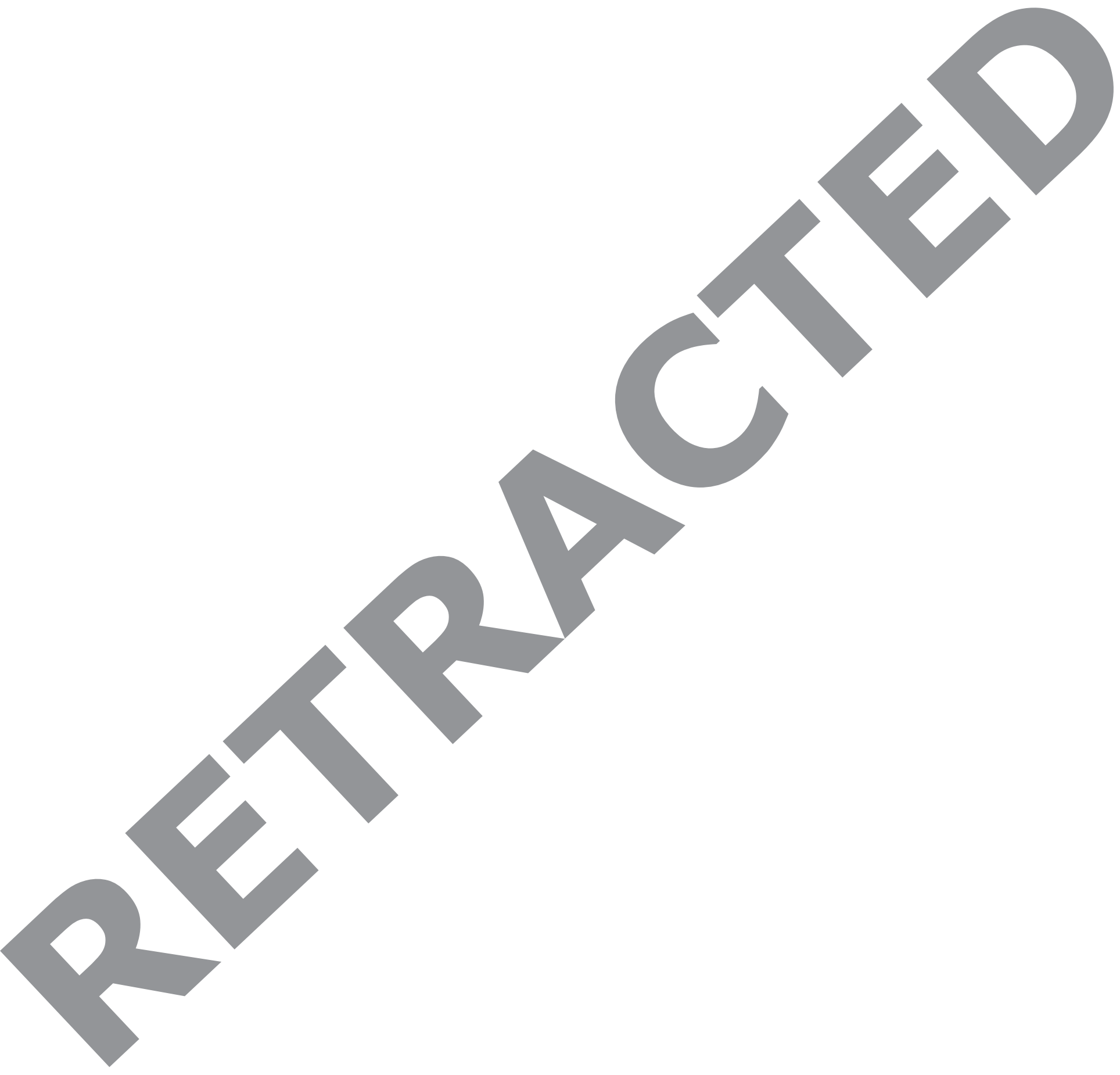

